\title{
The Rationale for the Method of Calculating the Angles of Arrival of Short Radio Waves Taking Into Account the Influence of Regular and Random Inhomogeneities of the Ionosphere
}

\author{
Anatoly I. Agaryshev*a and Minh G. Nguyen ${ }^{\mathrm{b}}$ \\ arkutsk National Research Technical University \\ 83 Lermontova Str., Irkutsk, 664074, Russia \\ ${ }^{b}$ Le Quy Don Technical University \\ 236 Hoang Quoc Viet Str., Ha Noi, Viet Nam
}

Received 17.03.2017, received in revised form 01.03.2019, accepted 10.05.2019

The article presents a reasonable method of calculating the angles of elevation of short radio waves with the influence of regular and random inhomogeneities of the ionosphere. The method calculates short radio waves (HF) through the horizontal inhomogeneous scattering ionosphere. The technique is based on application of the law of refraction of Snell's for well-known models of the ionosphere and its evolution in the irregular parts. The description of the program to calculate the angles of radiation and reception $H F$ is presented. The results of calculating the angles of arrival are compared with measurements of angles of arrival of $\mathrm{HF}$. We obtained the best agreement between the experimental and the calculated resultsl of arrival angles of HF than for the regular ionosphere. The use of techniques is discussed in the article.

Keywords: calculation of arrival angles of $H F$ radio waves, radio wave propagation, ionosphere model, optimization of radiation pattern.

Citation: Agaryshev A.I., Nguyen M.G. The rationale for the method of calculating the angles of arrival of short radio waves taking into account the influence of regular and random inhomogeneities of the ionosphere, J. Sib. Fed. Univ. Eng. technol., 2019, 12(5), 573-584. DOI: 10.17516/1999-494X-0157.

(C) Siberian Federal University. All rights reserved

This work is licensed under a Creative Commons Attribution-NonCommercial 4.0 International License (CC BY-NC 4.0)

* Corresponding author E-mail address: aai.irk@mail.ru 


\title{
Обоснование методики расчета углов
}

\section{прихода коротких радиоволн \\ с учетом влияния регулярной \\ и случайной неоднородности ионосферы}

\author{
А.И. Агарышев ${ }^{\text {, }}$ М.Ж. Нгуен \\ ${ }^{a}$ Иркутский национальный исследовательский технический университет \\ Россия, 664074, Иркутск, ул. Лермонтова, 83 \\ ${ }^{\sigma}$ Технический универтитет имени Ле Куй Дона \\ Вьетнам, Ханой, ул. Хоанг Куок Вьет, 236
}

Статья содержит обоснованную методику расчета углов прихода коротких радиоволн с учетом влияния регулярной и случайной неоднородности ионосферы. Представлена методика расчета коротких радиоволн (КВ) через горизонтальную неоднородную рассеиваюшую ионосферу. Методика основана на применении закона преломления Снеллиуса для известной модели ионосферы и ее развитии в нерегулярной части. Дано описание программы расчета углов излучения и приема КВ. Результаты расчета углов прихода сравниваются с результатами измерений углов прихода КВ. Получено лучшее, чем для регулярной ионосферы, соответствие экспериментальных и расчетных углов места КВ. Обсуждаются вопросы использования методики.

Ключевые слова: расчет углов прихода коротких радиоволн, распространение радиоволн, модель ионосферы, оптимизация диаграмм направленности.

\section{Introduction}

Known method of predicting elevation angles is recommended for the practical use by International consultative Committee on radio (CCIR). This method based on the setting of parameters of the ionosphere and the characteristics of the radio waves. It is implemented in the form of a computer program, which provides high speed of calculations of characteristics of short radio waves (HF) [1]. However, the CCIR method does not account for regular (predictable) changes in the ionospheric parameters along the radio links, i.e., does not account for possible differences between average values of angles of radiation and reception of HF in the vertical plane. There are also methods based on numerical integration of the system of radial equations to the ionosphere with changing in vertical and horizontal directions of the electron density N. These methods (for example, we can mention the work of V.I. Sazhin [2]) provide prediction results of the arrival and elevation angles more precisely compared to ones given by CCIR method. However, these methods do not provide high speed of calculating characteristics HF radio waves.

The aim of this work is to develop a more rapid method of calculating the angles of arrival of HF in the horizontally inhomogeneous scattering ionosphere and demonstrate its use on real paths.

\section{A mathematical model of the ionosphere}

In a layer with considering random disturbances of trajectories only in the lower part of the layer, the law of refraction is employed for constructing trajectory of HF radio waves. The angle at which 
radio wave enters the ionosphere $\varphi$ (angle of incidence) and the angle at which radio wave comes out of the ionosphere $\varphi_{B}$ are experienced random perturbations $\gamma 1, \gamma 2$ (scattering parameter). These random perturbations have the same characteristics, they distribute by the normal law.

In order to determine a value of scattering parameter (in degree), we use the method that was presented in work of A.I. Agaryshev [3]. We choose on the Earth's surface segments with length of $\Delta$ and for rays with propagation length of $D i$, getting in the k-th segment, we calculate the mean values of elevation angles, arrival angles and reflection heights of radio waves $\theta_{k}, \beta_{k}, h_{k}$ respectively, and we can calculate the standard deviations of these averages $\sigma$. By changing the value of scattering parameter to match the measured and the calculated standard deviations allows us to determine the value of scattering parameter for the specific conditions. The characteristic scale of disturbances $s$ at height of $100 \mathrm{~km} \approx 100 \mathrm{~m}$, when the height increases to $300 \mathrm{~km}$ the characteristic scale of disturbances increases to $100 \mathrm{~km}$. The degree of the disturbance effect on the radio trajectory is defined by relation $\Delta \chi / \mathrm{s}$, where $\Delta \chi=\Delta N / N-$ a disturbance of the electron concentration, it displays in percent, $s$ - characteristic scale of disturbances. It was known that $\Delta \chi \approx 1 \%$ at height of $100 \mathrm{~km}$ and $\Delta \chi \approx 10 \%$ - at height of $300 \mathrm{~km}$, therefore relation $\Delta \chi / s$ at the height of $100 \mathrm{~km}$ is over 100 times in compared with the relation $\Delta \chi / s$ at the height of $300 \mathrm{~km}$.

The method of construction of trajectories HF radio waves is based on application of the modified Snell's law for a thick layer of the ionosphere. For a thick layer Snell's law is given by formula [4]:

$$
n \cdot R \cdot \sin (\varphi)=n_{1} \cdot R_{1} \cdot \sin \left(\varphi_{1}\right),
$$

where $n, n_{1}$ - refraction coefficients of environment at a level of " $\mathrm{n}$ " and " 1 ", $R, R_{1}$ - radius from the Earth's center to the level " $\mathrm{n}$ " and " 1 ", $\varphi$ and $\varphi 1$ - angles between the path of radio wave and the radius $R, R_{l}$. The electron density is defined in accordance with the ionospheric model [5].

According to Fig. 1 trajectory HF radio waves consists of three parts: 1) a direct path between the transmitter and lower boundary of the reflective layer, 2) a curved path in the reflective layer, 3) a direct path between the lower boundary of this layer and the receiver. The method of construction of trajectory HF radio wave at path 2 is to divide it into equal segments, the length of these segments is substantially smaller than the total length of the curved path. Then the law (1) is applied sequentially to each of segments.

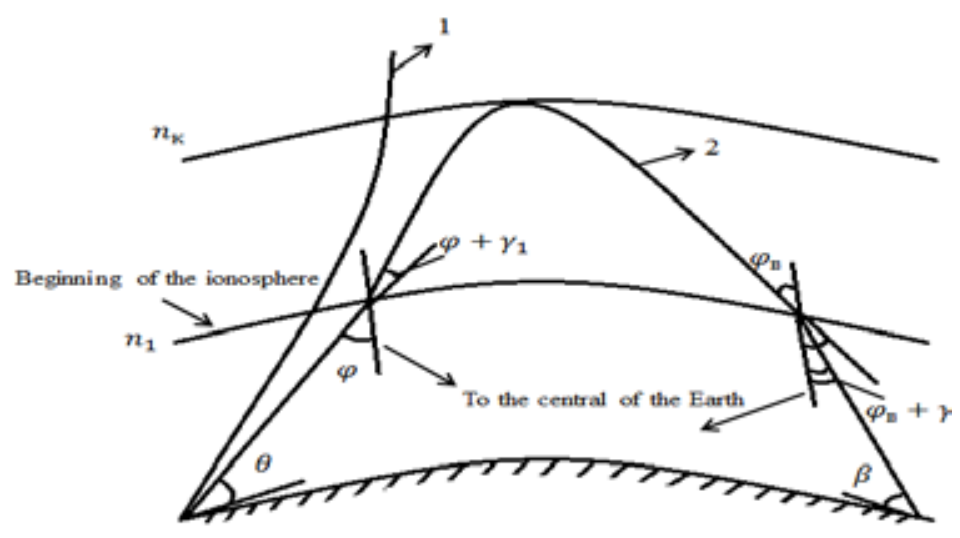

Fig. 1. The model of "beginning of the ionosphere": 1 - refraction ray, 2 - reflection ray

$$
-575-
$$




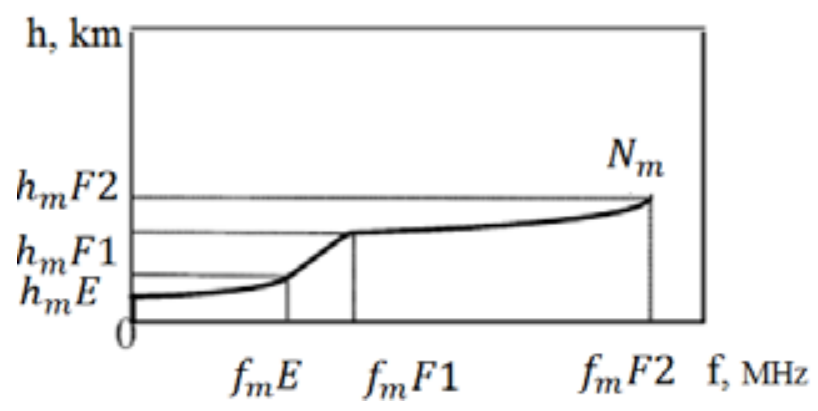

Fig. 2. The model of plasma frequencies for the ionospheric layers $E, F 1, F 2$ [5]

Then, a description of three-layer model of the ionosphere and mathematical expression of height dependence of the plasma frequency of ionospheric layers $E, F 1, F 2$ are given (Fig. 2). According to this model, the plasma frequencies are quadratic functions of height for layers $E$ and $F 2$.

For the layer E: $h_{m} E=110 \mathrm{~km}$, semi-thickness $y_{m} E=20 \mathrm{~km}, f_{\text {plas }}(h)=f_{m} E \cdot \sqrt{1-\left(\frac{h-h_{m} E}{y_{m} E}\right)^{2}}$.

When $110 \leq \mathrm{h} \leq h_{m} F 1$ (layer $\left.F 1\right)$

$$
f_{\text {plas }}(\mathrm{h})=f_{m} E \cdot\left(h \cdot 0.225+h_{m} F 1-1.225 \cdot h_{m} E\right) /\left(h_{m} F 1-h_{m} E\right) ;
$$

When $h_{m} F 1 \leq \mathrm{h} \leq h_{m} F 2$ (layer $\left.F 2\right): f_{\text {plas }}(h)=f_{m} F 2 \cdot \sqrt{1-\left(\frac{h-h_{m} F 2}{y_{m} F 2}\right)^{2}}$.

\section{A method for constructing trajectory $\mathrm{HF}$ radio wave}

When taking into account the gradient of electronic concentration in horizontal direction of HF radio waves, the formula of refraction law as follows:

$$
n_{k} \cdot R_{k} \cdot \sin \left(\varphi_{k}\right)-n_{k-1} \cdot R_{k-1} \cdot \sin \left(\varphi_{k-1}\right)=-\int_{S\left(R_{k-1}\right)}^{S\left(R_{k}\right)} \frac{\partial n}{\partial \theta} \cdot d S,
$$

where $\frac{\partial n}{\partial \theta}$ - the gradient of refractive index; $\mathrm{d} S$ - the element of trajectory radio wave.

The right part of the equation (2) can be calculated approximately according to a formula:

$$
\int_{S\left(R_{k-1}\right)}^{S\left(R_{k}\right)} \frac{\partial n}{\partial \theta} \cdot d S \approx \frac{\partial n}{\partial \theta} \cdot\left(S\left(R_{k}\right)-S\left(R_{k-1}\right)\right)=\frac{\partial n}{\partial \theta} \cdot \Delta S,
$$

where $\Delta \mathrm{S}=\mathrm{S}\left(\mathrm{R}_{1}\right)-\mathrm{S}\left(\mathrm{R}_{0}\right)-$ a calculation step along trajectory.

For a small increment of central angle $\Delta \theta$ (Fig. 3), we have an approximate expression:

$$
\Delta \theta \approx \sin (\Delta \theta)=\frac{d x}{R_{k-1}} .
$$

Where $\mathrm{dx}$ - an increment of distance by one moving step of radio waves in the ionosphere, $R_{k-1}-$ a radius between the central of the Earth and a starting point of $k$-th moving step.

In order to determine a value of refractive index $n$, we use a known formula: 


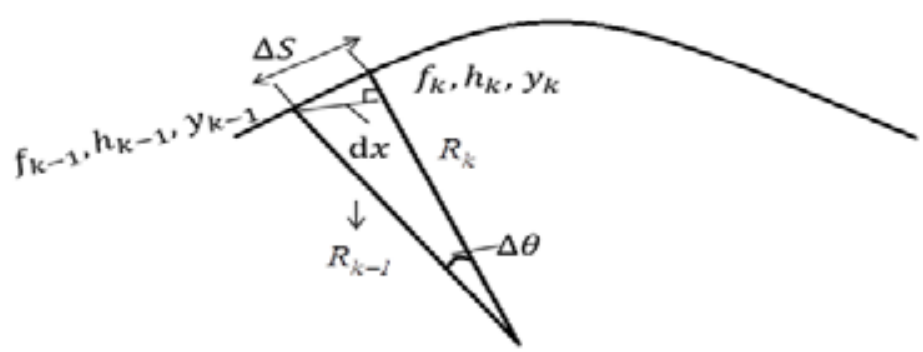

Fig. 3. Calculation of gradient of refractive index with an increment of central angle $\Delta \theta$

$$
n=\sqrt{1-\left(\frac{f_{\text {plas }}}{f}\right)^{2}} .
$$

Where $f, f_{\text {plas }}$ - a carrier and a plasma frequencies respectively.

By using the three-layer model of the ionosphere and the expression (4), the value of refraction index can be defined through the critical frequency, the height of maximum ionization, the semithickness and a height of current point:

In the layer $E$ :

$$
n(h)=\sqrt{1-\left(\frac{f_{m} E}{f}\right)^{2} \cdot\left[1-\left(\frac{h-h_{m} E}{y_{m} E}\right)^{2}\right]} .
$$

In the layer $F 1$ :

$$
n(h)=\sqrt{1-\left(\frac{f_{m E}}{f}\right)^{2} \cdot\left(\frac{h \cdot 0.225+h_{m} F 1-1.225 \cdot h_{m} E}{h_{m} F 1-h_{m} E}\right)^{2}} .
$$

In the layer $F 2$ :

$$
n(h)=\sqrt{1-\left(\frac{f_{m} F 2}{f}\right)^{2} \cdot\left[1-\left(\frac{h-h_{m} F 2}{y_{m} F 2}\right)^{2}\right]} .
$$

With a very small value of $\partial \theta$, by taking into account the expression (3), we can calculate the gradient of refractive index as following:

$$
\frac{\partial n}{\partial \theta} \approx \frac{\Delta n}{\Delta \theta}=\frac{R_{k-1} \cdot\left[n\left(h_{k}\right)-n\left(h_{k-1}\right)\right]}{d x} .
$$

Where $n\left(h_{k-1}\right)$ and $n\left(h_{k}\right)$ - the values of the refractive index at the beginning and the end of the $k$-th step of the movement of radio waves, corresponding to the heights $h_{k-1}$ and $h_{k}$.

For each movement step of radio waves, we calculate the values of critical frequencies of the ionospheric layers $\mathrm{E}$ and $\mathrm{F} 2\left(f_{m} E, h_{m} F 2\right)$ and the height of maximum ionization $h_{m} F 2$. At the end of the movement step we find gradient of refraction index $\frac{\partial n}{\partial \theta}$ by formula (5).

Then, by the expression of the Snell's law (2) we can calculate the angle of incidence for a next movement step of radio wave:

$$
\begin{gathered}
\sin \left(\varphi_{k}\right)=\frac{n_{k-1} \cdot R_{k-1} \cdot \sin \left(\varphi_{k-1}\right)-\frac{\partial n}{\partial \theta} \cdot \Delta S}{n_{k} \cdot R_{k}} . \\
-577-
\end{gathered}
$$


Radio wave is reflected from the ionosphere at the height where the angle of incidence equals to $90^{\circ}$.

\section{A calculation program of arrival angles of HF radio waves}

The program provides two modes of calculation: the first mode - calculate diurnal variation of arrival angles of considered mode of radio wave in a receiving point. The second mode - predict elevation angles and arrival angles of all modes of HF radio waves that are taken in a given area at a given specific time. Input data as follows: date, time, the average number of sunspot - the Wolf number (W) that corresponds to the given date, geographical coordinates of the transmitter and the receiver, the scattering intensity $s$ that can be determined by method in work [3], a minimum and a maximum of elevation angle, step of angle $\Delta \theta$, calculation step along trajectory radio wave $\Delta S$.

By using the input data, block 1 determines the parameters of the ionosphere $f m E$, $f m F 2, M(3000)$ $F 2$ that is close to a transmitter and a receiver using table-valued parameters of vertical sounding (VS) of the ionosphere, measured in days and hours of experimentation. Then, we define the peak height of the layer F2 of points of transmission and reception according to the formula developed in [3]:

$$
h_{m F 2}=\frac{1490}{\sqrt{M(3000)^{2}-1}}-176 .
$$

Unit 2 calculates the length of the route D and the azimuth of A radio link according to the specified geographical coordinates transmission and reception. Unit 3 implements calculations of angles of radiation and reception for each value of the angle of radiation. The values of the radiation angle changes from $\theta$ min to $\theta$ max in increments of $\Delta \theta$. The output from block 3 is a data array of angles of radiation and reception of radio waves received at the point of reception. In block 4 , average values of angles of radiation and reception are calculated ( $n-$ number of hits). Fig. 5 shows the interface of the program. Unit 6 displays graphical and tabular results of calculations.

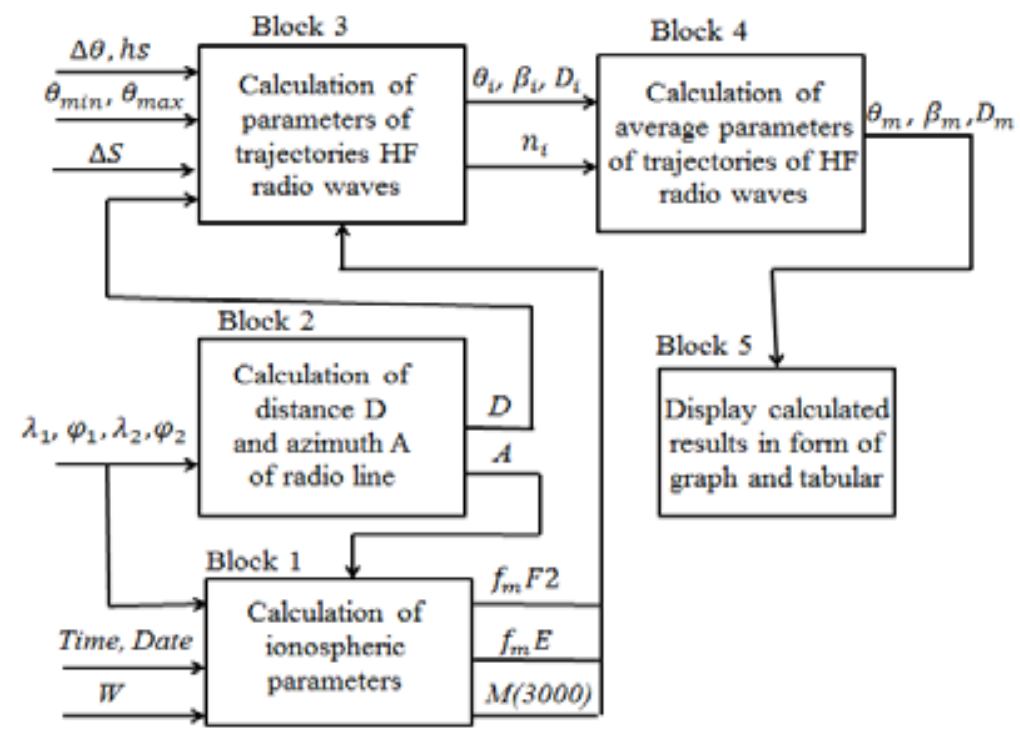

Fig. 4. A block-diagram of the program 


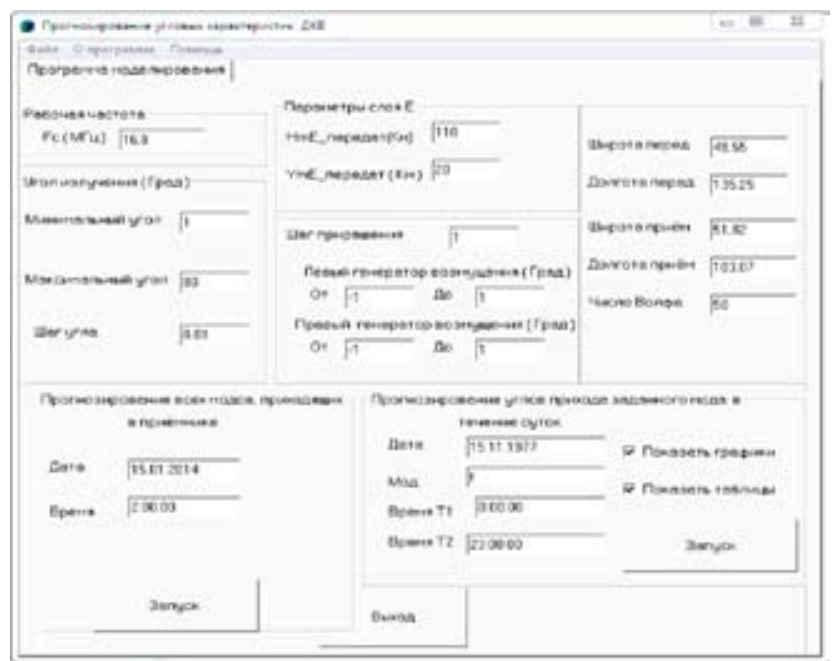

Fig. 5. Interface of the prediction program of arrival angles HF radio waves [6]
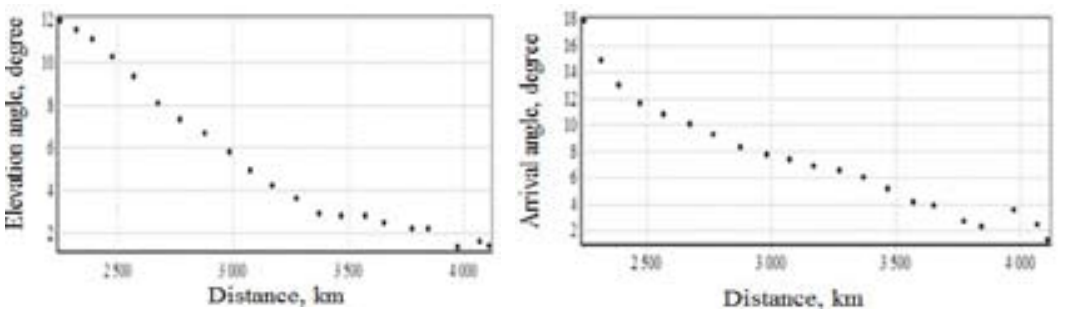

Fig. 6. Dependence of elevation angles and arrival angles on distance of mode $1 \mathrm{~F} 2$ with $f=18 \mathrm{MHz}$

Fig. 6 shows prediction results of elevation and arrival angles of HF radio waves in the form of graphs. Obviously, the elevation angles in this case are less than the arrival angles.

\section{Comparisons with measured results}

Examples of using the program for calculating arrival angles are presented below. On path Khabarovsk - Irkutsk the average values of measured data of arrival angles for moths in years [3] were used. We can see on Fig. 7 that, the calculated results (that equal to $8^{\circ}$ ) of method that is described in work [1] are less agreement with the experiments than the calculated results of presented method. Difference between calculated results of the proposed method and experiment data is caused by differences between prediction results of ionospheric parameters and actual parameters.

As the next example, predictions of arrival angles of HF radio by paths Moscow - Rostov-on-Don and Minsk - Rostov-on-Don are presented. The calculated results are compared with the experimental data of mode 1F2. The description of experiment were presented in [7]. The Wolf number was 72 in November, 90 in December by data in [8]. The calculated results from Fig. 8 have showed that, in the time interval from 5:00 to 6:00 MSK (Moscow standard time) the average value of arrival angles is $35^{\circ}$. The Agreement between the calculated results and experimental data of mode $F 20$ (an ordinary component of mode F2 that is shown by the arrow) is good as shown in Fig. 8. 


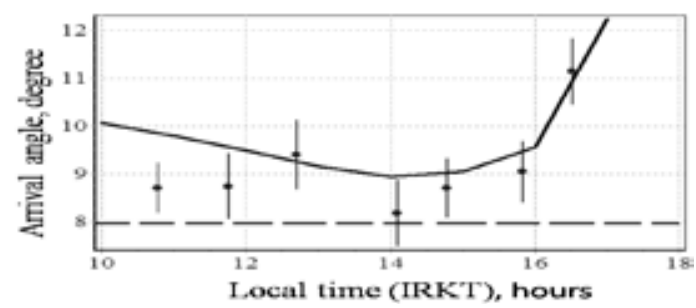

Fig. 7. Calculated results by method [1] (dashed curve), calculated results by proposed method (solid curve) and experimental results (points with confident limits) of dependence of arrival angles HF radio waves on local time in the middle of path Khabarovsk - Irkutsk in October
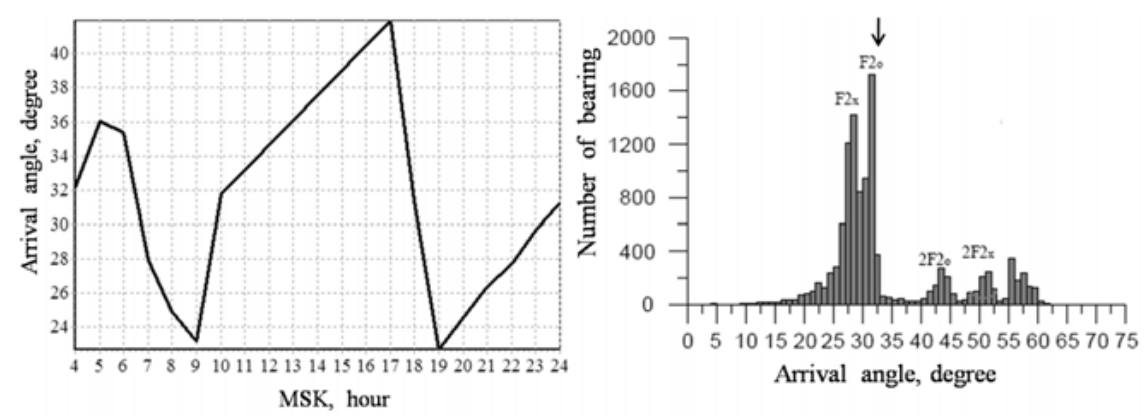

Fig. 8. The dependence of arrival angles of HF radio waves on time by path Moscow - Rostov-on-Don (left) and experimental distribution of arrival angles (right), 23.11.2013, 5:00-6:00 MSK f=4.996 MHz [7]
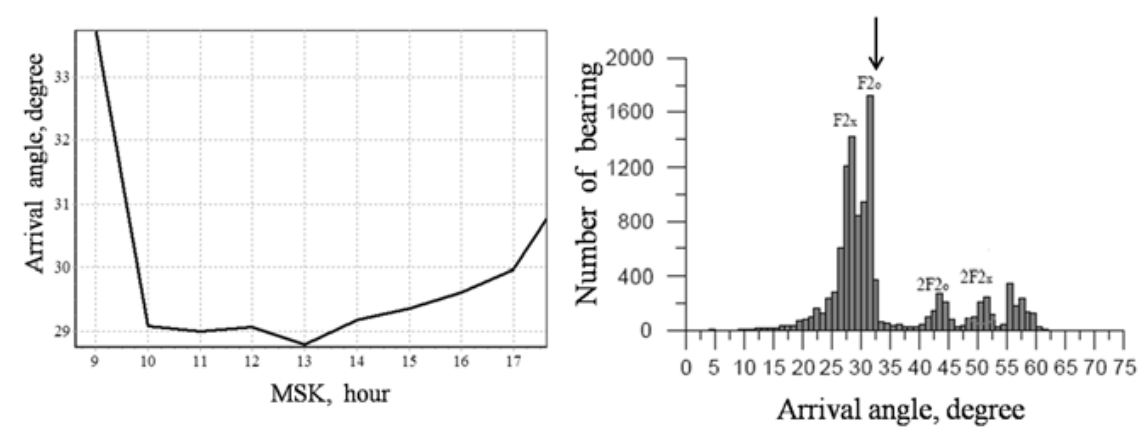

Fig. 9. Dependence of arrival angles of HF radio waves on time by path Moscow - Rostov-on-Don and experimental distribution of arrival angles, 23.11.2013, 9:00 - 10:00 MSK, f =9.996 MHz [7]

Fig. 9 shows that in the time interval from 9:00 to 10:00 MSK the angles of arrival HF radio vary in the range of 29 to $34^{\circ}$ and the average value of arrival angles is $32^{\circ}$. These calculated results have a good agreement with measured results of mode F20 - the ordinary component of mode 1F2 that is presented in the same figure.

It notes that there was not observed mode $2 \mathrm{~F} 2$ from prediction results in range of 9:00 to 10:00 MSK with transmitting frequency of $9.996 \mathrm{MHz}$ and in range of 5:00 to 6 MSK with transmitting frequency of $4.996 \mathrm{MHz}$ although by experimental data (Fig. 8 and 9, right) this mode was obtained. In order to explain this phenomenon, a maximum usable frequency of mode $2 \mathrm{~F} 2$ - (MUF) $2 \mathrm{~F} 2$ 
was calculated for path Moscow - Rostov-on-Don by the method that is presented in work [3]. The calculated results of (MUF) 2F2 in 5:00 and 6:00 (MSK) are 3.4 and 3.95 MHz respectively, at 9:00 and 10:00 AM (MSK) - (MUF) 2F2 are 7.45 and $8.3 \mathrm{MHz}$ respectively. These calculated results show that, theoretically, in the range of 5:00 to 6:00 MSK with transmitting frequency $4.996 \mathrm{MHz}$ modes $2 \mathrm{~F} 2 \mathrm{can}$ not be observed and in the range of 9:00 to 10:00 MSK with transmitting frequency $9.996 \mathrm{MHz}$ modes 2F2 also can't be observed. In spite of this, practically, propagations of HF radio with transmitting frequency higher MUF 2F2 are possible (as were shown in Fig. 8, 9) by reasons of influences of the random inhomogeneous ionosphere. There are two types of random inhomogeneous ionosphere: 1) the random small-scale inhomogeneities (characteristic size $<1 \mathrm{~km}$ ) that is located lower reflected layer. 2) the random large-scale inhomogeneities (characteristic size $>100 \mathrm{~km}$ ) that is related with traveling ionospheric disturbances (TIDs). In a work [3], the method "equal MUF" is presented that has given the same data of calculation MUF 2F2.

From the graph in Fig. 10, we can note that the average value of arrival angles of mode F2 in the range from 13:00 to $14: 00 \mathrm{MSK}$ is $33^{\circ}$. These results are consistent with measured results of the ordinary component of mode $1 \mathrm{~F} 2$.

From graph in Fig. 11 (left), the average value of arrival angles from 14:00 to 15:00 MSK can be determined and it equals to $23.5^{\circ}$. This calculated result is more than experimental data on $2^{\circ}$. This deviation is quite acceptable with considering of reliability of determining of input data.
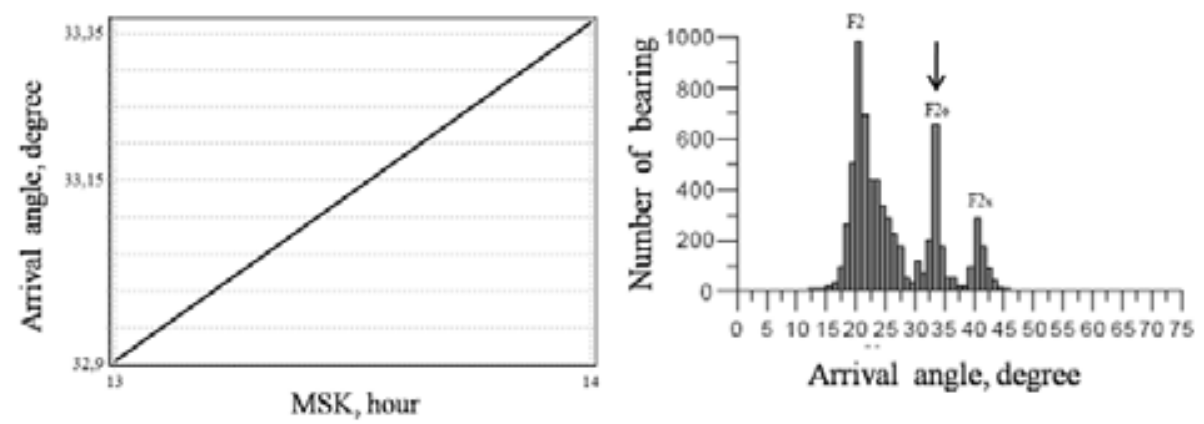

Fig. 10. Variations of arrival angles of HF radio waves by path Moscow - Rostov-on-Don and experimental distribution of arrival angles, 09.12.2013, 13:00-14:00 MSK, $\mathrm{f}=14.996 \mathrm{MHz}$ [7]
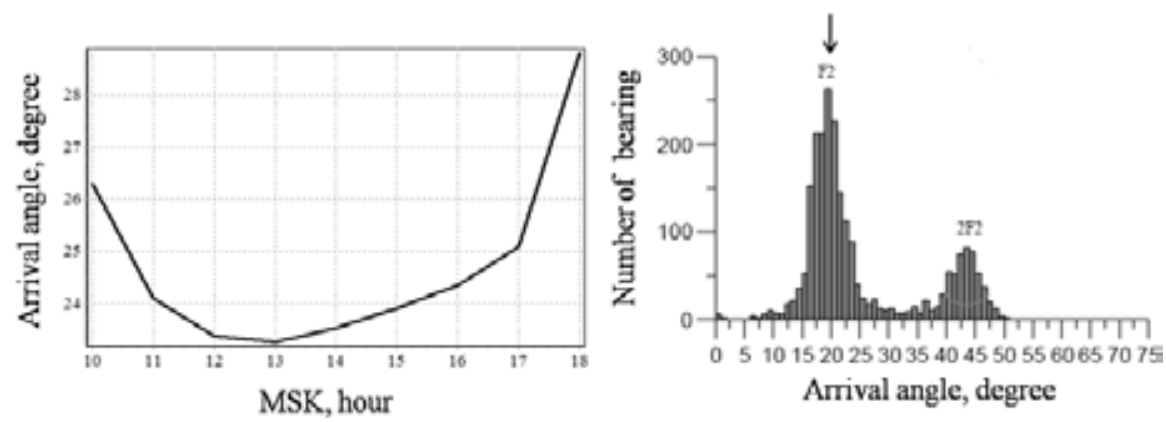

Fig. 11. Variations of arrival angles of HF radio waves by path Minsk - Rostov-on-Don and experimental distribution of arrival angles, 01.12.2013, 14:00-15:00 MSK, $\mathrm{f}=11.730 \mathrm{MHz}$ [7] 


\section{Optimization of antenna diagram}

In order to design HF antennas, it is very important to give the angles of arrival of HF radio waves. We can use the proposed program for calculating arrival angles. Let us give an example of design of a horizontal rhombic antenna for path from Khabarovsk to Irkutsk with operating frequency 16.8 MHz. The radiation pattern in the vertical plane of horizontal rhombic antenna is given by an expression [9]:

$$
F(\theta)=\frac{8 \cdot \cos (\phi)}{1-\sin (\phi) \cdot \cos \left(\theta_{m}\right)} \cdot \sin ^{2}\left\{\frac{k \cdot l_{p}}{2}\left[1-\sin (\phi) \cdot \cos \left(\theta_{m}\right)\right]\right\} \cdot \sin \left(k \cdot H_{P} \cdot \sin \left(\theta_{m}\right)\right.
$$

Where $\theta_{m}$ - an arrival angle HF radio wave, $\phi-$ a half of obtuse angle of rhombic, $l_{p}-$ a length of sides of rhombic, $H_{\Pi}-$ a suspension height above ground of antenna.

Using the proposed program, we can determine the radiation pattern for the average angle of arrival on path Khabarovsk-Irkutsk with an operating frequency of $16.8 \mathrm{MHz}$. In order to solve this problem, firstly, a prediction of arrival angle HF radio on route Khabarovsk - Irkutsk is carried out. Further, by using the calculation results, we can determine the average value of the arrival angles of radio waves in year. The calculated results were shown in Table.

Following the table, the average value of arrival angles of radio waves equals to $11.2^{\circ}$ in year. From the handbook [9], we can choose the rhombic antenna RH(65/4)1 with parameters $\phi=65^{\circ}, l=4 \lambda_{0}$, $H=\lambda_{0}$ with a maximum of the main lobe of the radiation pattern, which corresponds to the calculated arrival angle of mode $1 \mathrm{~F} 2$ of $\mathrm{HF}$ radio waves, the minimum of radiation pattern corresponds to arrival angles of mode 2F2 (Fig. 12).

Conclusions. This article successfully solved the problem of analysis of using the proposed program to solve practical problem, including:

Table. The average values of arrival angles HF (in deg) waves radio by path Khabarovsk - Irkutsk

\begin{tabular}{|c|c|c|c|c|c|c|}
\hline Months & January & February & March & April & May & June \\
\hline$\beta_{c p}$ & 10.2 & 10 & 10.5 & 11 & 13.7 & 13.2 \\
\hline Months & July & August & September & October & November & December \\
\hline$\beta_{c p}$ & 13.2 & 12.7 & 11.3 & 9.7 & 9.4 & 9.0 \\
\hline
\end{tabular}

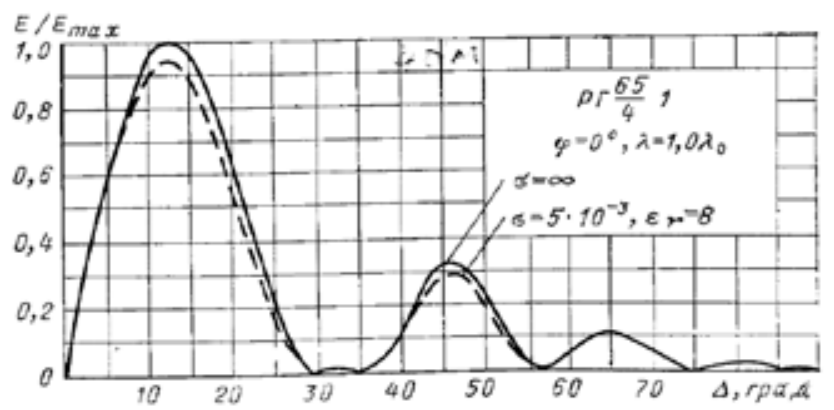

Fig. 12. Radiation pattern in the vertical plane of antenna RH (65/4)1 [9] 
1) Developing the method and building a program to calculate the angles of arrival HF radio waves. The method based on application of modified Snell's law with considering the influence of gradient of refractive index on trajectories HF radio waves in the horizontally inhomogeneous scattering ionosphere.

2) The comparisons with measured results by paths Khabarovsk - Irkutsk, Moscow - Rostov-onDon, Minsk - Rostov-on-Don were carried out. As a result, our calculation agrees much better with measured data, compared to calculations from other methods based on the horizontal homogeneous ionosphere.

3) Showing that the proposed program allows designing radiation pattern of HF antenna with the main lobe that corresponds to mode $1 \mathrm{~F} 2$ and the minimum corresponds to mode $2 \mathrm{~F} 2$.

The causes of deviations between the calculation results of arrival angles of HF radio waves and the measured results are obvious. The first deviation can be reduced by taking into account the extraordinary components of radio waves, the second deviation is relates to using a more efficient method for calculating MUF 2F2 that was known as reception of hops with equal MUF [3]. In our future works, we will work on improving the performances of the program and the proposed method to reduce the deviations.

\section{References}

[1] A simple HF propagation method for MUF and field strength:Document CCIR 6/288. - CCIR XVIth Plenary Assembly. Dubrovnik, 1986. 34 p.

[2] Afanasiev N.T., Tinin M.V., Sazhin V.I. et al. Effects of large-scale clouds of ionospheric irreqularites on the propagation of high-frequency radio waves. J. Of Atmospheric and Solar-teorestrial physics. Pergamon, London, 1998, 60, 1687-1694.

[3] Агарышев А.И., Агарышев В.А., Алиев П.М., Труднев К.И. Системы коротковолновой радиосвязи с подавлением многолучевости сигнала: монография. Под ред. А.И. Агарышева. Иркутск: Изд-во ИрГТУ, 2009. 160 с. [Agarysev A.I. et al. Systems of shortwave radio with the suppression of multipath signal. Irkutsk: Publishing House of Irkutsk state technical University, 2009. 160 p. (in Russian)]

[4] Дэвис К. Радиоволны в ионосфере. М.: Мир, 1973. 502 с. [Davis K. Radio waves in the ionosphere. M.: Mir, 1973. 502 p. (in Russian)]

[5] Bradley P.A., Dudeney J.R. A simple model of the vertical distribution of electron concentration in the ionosphere. J. Atmos. Terr. Phys. 1973, 35(12), 2131-2146.

[6] Агарышев А.И., Жанг Н.М. Прогнозирование характеристик декаметровых радиоволн на неоднородной рассеивающей ионосфере. Свидетельство о государственной регистрации программы для ЭВМ №2015610215, заявка № 2014661368 от 10 ноября 2014 г., дата гос. регистрации Реестре программ для 12 января 2015 г. [Agaryshev A.I., Giang N.M. Forecasting characteristics of decameter radio waves on inhomogeneous scattering ionosphere. Certificate of state registration for program of the computer No. 2015610215, application number 2014661368 dated 10 November 2014, the date of the state. Registration Program Register on January 12, 2015 (in Russian)]

[7] Чайка Е.Г., Вертоградов Г.Г. Использование данных текущей диагностики ионосферы в задаче КВ-пеленгации и однопозиционного места определения. Распространение радиоволн: сб. докл. ХХIV Всерос. науч. конф. (Иркутск, 29 июня - 5 июля, 2014 г.): в 4 Т. Под ред. Д.С. Лукина

$$
-583-
$$


[и др.]. Иркутск: ИСЗФ СОРАН, 2014, 2, 41-44 [Chaika E.G. Using current diagnostic data of the ionosphere in the problem HF-direction finding and single point positioning. Chaika E.G., Vertogradov G.G. XXIV All-Russian Scientific.Conf. "Radio propagation”, June 29-July 5, 2014 [Collec. rep] to 4 Vol. Eds.: D.S Lukin [et al.]. Irkutsk: ISTP SB RAS, 2014, 2, 41-44 (in Russian)]

[8] Solar Physics. National Aeronautics and Space Administration [Electronic resource] Access: http://solarscience.msfc.nasa.gov/.

[9] Айзенберг Г.З. Коротковолновые антенныл. М.: Связьиздат, 1962. 815 с. [Eisenberg G.Z. Shortwave antennas. M.: Svyaz'izdat, 1962. 815 p. (in Russian)] 